\title{
Nezaposlenost i dugotrajna nezaposlenost doseljenih u Hrvatsku
}

DOI: $10.11567 / \mathrm{met} .32 .1 .3$ UDK: 331.56-054.72(497.5)"2007/201" Izvorni znanstveni rad Primljeno: 19. 03. 2015. Prihvaćeno: 15. 03. 2016.

\section{Valerija Botrić}

Ekonomski institut, Zagreb

vbotric@eizg.hr

\begin{abstract}
SAŽETAK
U Hrvatskoj u okviru migracijskih tema dominira pitanje emigracije, posebno mladih i obrazovanih, podjednako u literaturi i raspravama u široj javnosti. No aktivna migracijska politika nužno mora razmotriti i drugu stranu migracijskih kretanja. U kontekstu dugoročnih kretanja na hrvatskom tržištu rada, a uzimajući u obzir rašireni proces demografskog starenja, pitanje aktivne imigracijske politike sve će više dolaziti do izražaja. Osnovni je cilj istraživanja analizirati položaj imigranata na hrvatskom tržištu rada. Temeljem podataka Ankete o radnoj snazi Državnog zavoda za statistiku analiziraju se razlike između karakteristika zaposlenih i nezaposlenih osoba koje su se doselile u Hrvatsku, s ciljem identificiranja prediktorâ statusa nezaposlenosti. Dodatni segment koji se istražuje jest postoje li razlike između kratkotrajno i dugotrajno nezaposlenih doseljenih osoba u Hrvatskoj te koji su prediktori statusa dugotrajne nezaposlenosti. Empirijska analiza provedena je za dvije odvojene godine da bi se razmotrilo u kojoj je mjeri dugotrajna recesija dodatno utjecala na položaj doseljenika na hrvatskom tržištu rada. Prva godina (pretkrizna) jest 2007., a druga (krizna) 2012.
\end{abstract}

KLJUČNE RIJEČI: nezaposlenost, dugotrajna nezaposlenost, doseljenici, tržište rada, Hrvatska

\section{UVOD}

U literaturi često nailazimo na tvrdnje kako su imigranti posebno ranjiva skupina na domicilnom tržištu rada zemalja u koje se useljavaju (Büchel i Frick, 2005; Bernardi, Garrido i Miyar, 2011; Fullin i Reyneri, 2011; Kogan, 2011). Postavlja se pitanje u kojoj se mjeri slične tvrdnje mogu potvrditi ili osporiti kad je riječ o hrvatskom tržištu rada. To je pitanje posebno zanimljivo ako ga stavimo u kontekst rasprave o potencijalnim budućim potrebama na tržištu rada, koje će se zbog sadašnjeg trenda emigracije iz Hrvatske i naglašenog procesa demografskog starenja vjerojatno javiti kao važna tema znanstvenih i stručnih rasprava. Radi doprinosa raspravi ovaj rad razmatra ishode na tržištu rada doseljenih u Hrvatsku. 
U ovom se radu analiziraju ishodi na tržištu rada osoba doseljenih $u$ Hrvatsku kroz dvije odvojene komponente koje prethodno nisu empirijski istraživane. Prva se odnosi na istraživačko pitanje koje karakteristike samih osoba pridonose njihovu zapošljavanju te se tako primjenom uobičajenih prediktora zapošljavanja (dob, spol, zanimanje, obrazovanje i slično) ispituje vjerojatnost nezaposlenosti u odnosu na status zaposlenosti. Analizirane su dvije godine - 2007. i 2012. Druga godina odnosi se na razdoblje kada se hrvatsko gospodarstvo već godinama nalazi u dubokoj ekonomskoj krizi te se $u$ radu pokušava identificirati u kojoj se mjeri rezultati analize razlikuju u razdoblju kada možemo očekivati veću vidljivost učinaka krize na tržište rada.

Druga komponenta koja se analizira vezana je uz trajanje nezaposlenosti. Naime osim same činjenice da je u Hrvatskoj duži niz godina raširena nezaposlenost poseban je problem njezino izrazito dugo trajanje, koje ima mnoštvo negativnih posljedica na pojedince, ali i na cjelokupno tržište rada. Stoga se analizira u kojoj su mjeri doseljeni u Hrvatsku izloženi dugotrajnoj nezaposlenosti te je li moguće identificirati karakteristike koje pridonose statusu dugotrajne nezaposlenosti doseljenih osoba.

Rad je strukturiran tako da drugo poglavlje sadržava kratki pregled relevantne literature, u trećemu se opisuje metodologija istraživanja i prikazuju osnovne karakteristike podataka upotrijebljenih u analizi, četvrto se bavi prediktorima statusa nezaposlenosti ( $u$ odnosu na status zaposlenosti) osoba doseljenih u Hrvatsku te sadržava rezultate empirijske analize i diskusiju, $\mathrm{u}$ petome se analiziraju prediktori dugotrajne nezaposlenosti $\mathrm{u}$ odnosu na kratkotrajnu) te se raspravlja o prikazanim rezultatima analize, a u zadnjemu se sažimaju izneseni zaključci i daju se preporuke za buduća istraživanja.

\section{PREGLED LITERATURE}

Teorijski koncepti vezani uz očekivanja o ishodima imigranata na lokalnom tržištu rada povezani su s hipotezama pretjerane ili nedovoljne asimilacije (Chiswick, 1978; Borjas, 1985). Ekonomska teorija uglavnom je bila usmjerena na pitanje učinka imigracije na lokalna tržišta rada (Todaro, 1969; Harris i Todaro, 1970), pri čemu su se karakteristike tržišta rada (rigidnost plaća, stopa nezaposlenosti i podzaposlenost) smatrale presudnima za ishod. Greenwood i McDowell (1986) stavljaju naglasak na elastičnost ponude i potražnje na tržištu rada, što uvodi pitanje razlika u specifičnim karakteristikama imigranata u odnosu na domaće stanovništvo. Zabrinu- 
tost za utjecaj imigranata na lokalna tržišta rada rezultirala je brojnim empirijskim istraživanjima, koja u pravilu pokazuju da je taj učinak relativno mali. Tako metaistraživanje koje su proveli Longhi, Nijkamp i Poot (2010) zaključuje da porast broja imigranata za jedan posto smanjuje prosječnu plaću na lokalnom tržištu rada za 0,029 \% i zaposlenost domaćeg stanovništva za $0,011 \%$.

Unatoč teorijskim predviđanjima koja naglašavaju potrebe za dodatnom radnom snagom empirijska istraživanja često pokazuju da imigranti čine izdvojenu skupinu na lokalnom tržištu rada koja se suočava s većom vjerojatnošću nepovoljnog ishoda (Bevelander i Irastorza, 2014; Jean i sur., 2010; de la Rica, Glitz i Ortega, 2013; Peracchi i Depalo, 2006). Istraživanja pokazuju da je to čest slučaj i u europskim zemljama, pri čemu Kahanec i Zaiceva (2008) naglašavaju da postoje velike razlike između novih i starih članica EU-a. Stoga promatrajući rezultate empirijskih istraživanja u drugim zemljama, ne možemo predvidjeti ishode imigranata na hrvatskom tržištu rada. Nedavna velika migracijska kretanja i dugotrajna ekonomska kriza nameću potrebu sličnih istraživanja za hrvatsko gospodarstvo.

Istraživanja pokazuju da se ishodi imigranata mijenjaju s poslovnim ciklusom (Dustmann, Glitz i Vogel, 2010), iako postoje naznake da je posljednja ekonomska kriza u tom pogledu različita od uobičajenih kretanja tijekom poslovnih ciklusa (de la Rica i Polonyankina, 2013). Očekivanja o ishodima na tržištu rada doseljenog stanovništva u europskim zemljama značajno su se promijenila tijekom posljednje ekonomske krize. Dok su prije krize istraživanja naglašavala potrebu za dodatnom radnom snagom zbog procesa demografskog starenja, pad potražnje na tržištu rada doveo je do toga da se na doseljeno stanovništvo gleda kroz prizmu povećanoga fiskalnog pritiska (Chaloff, Dumont i Liebig, 2012).

Pitanje koje se $u$ kontekstu imigranata posebno razmatra $u$ zapadnoeuropskim zemljama jest u kojoj mjeri imigranti, zbog relativno veće vjerojatnosti nepovoljnih ishoda na tržištu rada, predstavljaju dodatni teret za sustav socijalnih naknada. Istraživanja pokazuju da su imigranti u većoj mjeri korisnici sustava socijalnih naknada (Nannestad, 2007) i time dodatno opterećuju lokalni fiskalni sustav (De Giorgi i Pellizzari, 2009). Istraživači slično pitanje postavljaju i u kontekstu proširenja Europske unije. Boeri i Brücker (2005) naglašavaju da poticaj za migraciju raste, posebno za pojedince sa slabije razvijenim kompetencijama, kada na njihovu lokalnom tržištu poraste konkurencija na tržištu rada zbog doseljenog stanovništva.

Markaki (2014) zaključuje da su lokalna tržišta rada članica EU-a različita, ali su zbog tih specifičnih uvjeta uloge imigranata na tržištima također 
različite. Razlike između ishoda imigranata i domicilnog stanovništva $\mathrm{u}$ pravilu su veće u zemljama s većim udjelom imigranata. No sama struktura lokalnog tržišta rada također je važna. U zemljama s rigidnim zakonodavstvom imigranti će vjerojatnije biti zaposleni na privremenim poslovima te im prijeti veći rizik od nezaposlenosti tijekom krize, kada poslodavci kao prvu mjeru prilagodbe smanjenoj potražnji ne produžuju privremene ugovore o radu.

Za razliku od zapadnoeuropskih zemalja, u koje se često doseljavaju stanovnici iz udaljenih krajeva, pa i s drugih kontinenata, doseljeno stanovništvo u Hrvatsku uglavnom je iz susjednih zemalja. Stoga neki problemi s kojima se susreću doseljenici u Europi (na primjer jezične i kulturne barijere) kod većine doseljenih u Hrvatsku ne bi trebali predstavljati veliku prepreku. $U$ tom smislu temeljem istraživanja koja naglašavaju da imigranti koji ne dolaze iz udaljenih područja imaju relativno slične ishode na tržištu rada kao i domicilno stanovništvo (Cerveny i van Ours, 2013) možemo pretpostaviti da razlike u Hrvatskoj ne bi trebale biti velike. No Botrić (2015) pokazuje da ako se uspoređuju domicilno i doseljeno stanovništvo s istim karakteristikama (obrazovanje, spol, starost i zanimanje), stopa nezaposlenosti veća je, a stopa zaposlenosti niža za doseljeno stanovništvo u Hrvatskoj.

Istodobno, s postojećim velikim valom migracija naglasak u raspravama stavlja se na poticanje politika koje će pridonositi bržoj i lakšoj integraciji imigranata u lokalna društva (Kogan, 2015). Pretpostavka je da bi odgovarajuća politika integracije omogućila i veće vjerojatnosti za pozitivne ishode na tržištu rada. U tom kontekstu važno je pitanje odgovarajućeg iskorištavanja raspoloživoga ljudskoga kapitala koji pristiže migracijskim valom. U slučaju nezaposlenosti, bilo doseljenog, bilo domicilnog stanovništva, raspoloživi ljudski kapital propada. U nastavku se stoga posvećuje pozornost upravo pitanju koje karakteristike osoba doseljenih u Hrvatsku pridonose većem riziku od nezaposlenosti i dugotrajne nezaposlenosti.

\section{PODACI I METODOLOGIJA}

Za potrebe istraživanja upotrijebljeni su podaci bez identifikatora Ankete o radnoj snazi (ARS) koju redovito od 1998. provodi Državni zavod za statistiku. ${ }^{1}$ Analiziraju se podaci iz dvije odvojene godine-2007. i 2012. Iako Anketa o radnoj snazi od 2007. sadržava panel-komponentu, koja bi teoret-

Više o samoj metodologiji provedbe istraživanja Anketa o radnoj snazi može se pronaći u: Državni zavod za statistiku (2013). 
ski trebala omogućiti identifikaciju promjena analiziranih statusa na razini pojedinca, podaci kojima se raspolagalo tijekom ovog istraživanja nisu bili anonimizirani, već jednostavno nisu sadržavali identifikacijska obilježja. Osim same informacije o kojem je panelu riječ dodatnih informacija koje bi omogućile praćenje tijekom vremena ishoda na tržištu rada na razini pojedinca u raspoloživom izvoru podataka nije bilo. Stoga se dinamička analiza promjena na tržištu rada, koja bi se temeljila na longitudinalnom pristupu, nije mogla primijeniti.

Budući da podaci nisu anonimizirani, nije bilo moguće razlučiti u kojoj mjeri uvedena panel-komponenta može proizvesti pristranost $u$ samom uzorku, jer omogućuje ponavljanje odgovora istog ispitanika. Stoga su u analizu uključeni paneli samo kada se prvi put javljaju u uzorku. Konkretno, ako se isti panel javlja u tjednima 1 - 13 i $27-39$, u analizu su uključeni odgovori ispitanika dobiveni samo tijekom prvog vala ispitivanja. ${ }^{2}$

Analiza je usmjerena na ishode na tržištu rada svih doseljenih osoba u Hrvatsku bez obzira na njihovu narodnost, a ne na strane državljane koji rade u Hrvatskoj. Naime istraživanja poput Ankete o radnoj snazi u pravilu teže u uzorak uključiti strane radnike (European Commission, 2011) jer se okvir uzorka temelji na stalnom stanovništvu, dok su strani radnici u nekim slučajevima samo sezonski aktivni na domicilnom tržištu rada. ${ }^{3}$ Stoga uzorci Anketa o radnoj snazi u pravilu u manjem obujmu obuhvaćaju radnike sa stranim državljanstvom, ${ }^{4}$ ali u dovoljnoj mjeri mogu obuhvatiti osobe koje su se trajno doselile iz drugih zemalja. Važno je naglasiti da je osnovna

2 Isto načelo primjenjuju Drinkwater i Robinson (2011) te Nestić, Rubil i Tomić (2015).

3 Postoje i dodatni problemi s praćenjem stvarnoga kretanja stranih radnika na lokalnom tržištu rada. Strani radnici mogu biti prisutni zakonito i privremeno ili čak nezakonito, a oba slučaja možemo ilustrirati na primjeru Hrvatske. U slučaju zakonitih boravaka podaci Ministarstva unutarnjih poslova pokazuju strane osobe sa stalnim i privremenim boravkom u Republici Hrvatskoj. Tako se na primjer prema posljednjim objavljenim podacima može vidjeti da je od ukupnog broja osoba kojima je odobren privremeni boravak tijekom 2014., čak 39,8 posto boravilo sa svrhom rada. S druge strane, Državni inspektorat u svojim je redovitim godišnjim izvješćima objavljivao podatke o stranim radnicima koji su bez odgovarajuće dokumentacije bili identificirani na radu. Tako je na primjer 2012. Državni inspektorat identificirao ukupno 374 radnika bez odgovarajuće dokumentacije, dok je za istu godinu Ministarstvo unutarnjih poslova registriralo 4820 stranih radnika sa statusom odobrenoga privremenog boravka.

4 Upitnik Ankete o radnoj snazi sadržava pitanje o državljanstvu te se iz odgovora na njega može vidjeti da svi doseljeni analizirani u ovom radu imaju hrvatsko državljanstvo. 
namjena Ankete o radnoj snazi praćenje kretanja na nacionalnom tržištu rada ukupne populacije. Budući da se u ovom radu analizira samo jedan segment te populacije, ne možemo tvrditi da doista analiziramo reprezentativni uzorak. Stoga prikazani rezultati nisu projicirani pomoću dostupnih pondera na cijelu populaciju, već se mogu smatrati isključivo rezultatima na razini uzorka. ${ }^{5}$

Korisno je naglasiti da pojedine karakteristike uzorka ne odstupaju značajno od ukupne populacije. Usporedbom podataka iz ARS-a 2012. s onima iz popisa stanovništva možemo vidjeti da doseljene osobe čine 9,6 \% uzorka prema prvom izvoru podataka, odnosno 14,1 \% ukupnog stanovništva prema drugom izvoru podataka. Popis stanovništva pokazuje da je najveći udio doseljenih iz Bosne i Hercegovine, 44,8 \%, dok je taj podatak prema ARS-u 2012. sedamdeset posto. To upućuje da je rezultate doista nužno promatrati na razini uzorka te da je za njihovo poopćivanje potrebno provesti dodatna specifično usmjerena istraživanja.

Budući da je osnovni fokus analize usmjeren na ishode na tržištu rada, podaci su u cjelokupnome empirijskom dijelu ograničeni na ispitanike $u$ radno sposobnoj dobi između 15 i 65 godina. ${ }^{6}$

Deskriptivna analiza uzorka navedena je u tablici 1 . Navedene su prosječne vrijednosti određenih pokazatelja ili struktura uzorka prema karakteristikama koje se uobičajeno smatraju dobrim prediktorima za ishode na tržištu rada ${ }^{7}$. Način na koji su neke od navedenih varijabli definirane u konkretnoj primjeni, zahtijeva posebnu pozornost kako bi se podaci interpretirali na odgovarajući način. Stoga u nastavku slijedi detaljan opis varijabli upotrijebljenih u empirijskoj analizi.

5 S obzirom na navedeno Eurostat je 2008. proveo u okviru Ankete o radnoj snazi dodatni modul kako bi se istražili učinci migracija na domicilna tržišta rada. No Hrvatska nije bila obvezna provesti to istraživanje, pa rezultati za nju nisu raspoloživi.

6 U skladu s na primjer Zakonom o posredovanju pri zapošljavanju i pravima za vrijeme nezaposlenosti (čl. 10.) registrirane nezaposlene osobe kako ih prati Hrvatski zavod za zapošljavanje nalaze se u dobi od 15 do 65 godina (https:// statistika.hzz.hr/Default.aspx).

7 Vidjeti na primjer Arai i Vilhelmsson (2004), Unemployment Risk Factors... (2003), Thapa (2004), Prasad, (2003), Brown i Taylor (2008), Davia i MarcenaroGutiérrez (2007), Jones (1989), Blackaby i sur. (2007), Christensen (2001). 
Tablica 1. Zaposlenost, nezaposlenost i aktivnost doseljenih osoba u Hrvatskoj 2007. i 2012.

Table 1. Employment, unemployment and activity of immigrants in Croatia, 2007 and 2012

\begin{tabular}{|c|c|c|c|c|c|c|}
\hline & \multicolumn{3}{|c|}{2007.} & \multicolumn{3}{|c|}{2012.} \\
\hline & 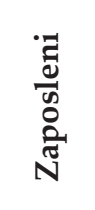 & 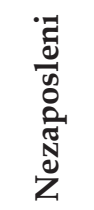 & 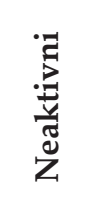 & 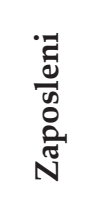 & 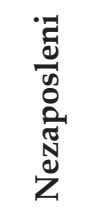 & 茌 \\
\hline Prosječna dob (godine) & 43,08 & 39,87 & 46,91 & 45,84 & 42,24 & 51,07 \\
\hline \multicolumn{7}{|l|}{ Bračni status (\%) } \\
\hline U (bračnoj) zajednici & 78,0 & 64,07 & 63,68 & 75,58 & 62,90 & 71,08 \\
\hline Razvedeni/udovci & 4,96 & 5,08 & 12,56 & 6,44 & 5,65 & 12,10 \\
\hline \multicolumn{7}{|l|}{ Područje stanovanja (\%) } \\
\hline U urbanim naseljima & 61,57 & 48,47 & 58,00 & 67,82 & 53,36 & 59,92 \\
\hline \multicolumn{7}{|l|}{ Stupanj obrazovanja (\%) } \\
\hline Osnovno & 20,15 & 29,83 & 56,06 & 18,15 & 26,15 & 48,02 \\
\hline Srednje & 61,36 & 61,69 & 39,76 & 66,01 & 66,43 & 47,83 \\
\hline Visoko & 18,49 & 8,48 & 4,19 & 15,84 & 7,42 & 4,15 \\
\hline \multicolumn{7}{|l|}{ Zanimanje (\%) } \\
\hline Vojna zanimanja & - & - & 3,59 & - & - & 4,35 \\
\hline Dužnosnici, direktori & 6,10 & - & 2,09 & 5,61 & 2,83 & 1,32 \\
\hline Stručnjaci & 9,30 & 2,71 & 1,35 & 14,52 & 3,18 & 3,21 \\
\hline Tehničari & 12,29 & 5,08 & 5,38 & 10,07 & 3,53 & 5,48 \\
\hline Službenici & 9,61 & 4,41 & 4,78 & 9,24 & 5,30 & 3,97 \\
\hline Uslužna zanimanja & 13,33 & 13,90 & 8,37 & 18,65 & 17,31 & 11,53 \\
\hline Poljoprivrednici & 8,37 & - & 3,14 & 7,10 & - & 1,32 \\
\hline Zanimanja u obrtu & 17,36 & 7,46 & 6,28 & 12,87 & 12,37 & 8,51 \\
\hline Rukovatelji postrojenjima & 11,67 & 8,14 & 9,72 & 9,08 & 11,31 & 13,42 \\
\hline Jednostavna zanimanja & 11,26 & 8,14 & 6,58 & 12,05 & 15,55 & 10,96 \\
\hline Bez radnog iskustva & & 46,78 & & & 26,86 & \\
\hline Veličina uzorka (N) & 968 & 295 & 669 & 606 & 283 & 529 \\
\hline
\end{tabular}

Napomena: - označuje mali broj opažanja

Izvori: Anketa o radnoj snazi 2007. i 2012., izračun autora 
U slučaju migracija razlike prema spolu mogu imati i značajniju ulogu, posebno kada je riječ o privremenom boravku stranaca radi zaposlenja (Azmat, Güell i Manning, 2006; Kerovec, 2003; Matković, 2008). Stoga je u empirijskim analizama upotrijebljena binarna varijabla koja poprima vrijednost »1 «ako je riječ o muškoj osobi.

Empirijska istraživanja ishoda na tržištu rada također pokazuju da obiteljski život često utječe na pojačano traženje posla ili dodatni trud na poslu kako bi se osigurala sredstva potrebna za život cijele obitelji. U Anketi o radnoj snazi razlikuje se šest kategorija bračnog stanja: neoženjen/neudana, oženjen/udana, udovac/udovica, razveden/razvedena, izvanbračni partner/ partnerica i odvojeni bračni partner/partnerica. Iz empirijske ocjene izuzeta je binarna varijabla »neoženjen/neudana « te se ocijenjene vrijednosti koeficijenata uz preostale dvije varijable promatraju u odnosu na tu kategoriju. Preostalih pet mogućih kategorija bračnog stanja grupirano je ovako: pod binarnom varijablom »u (bračnoj) zajednici« uključene su osobe koje su u podacima Ankete o radnoj snazi svrstane pod kategorijama oženjen/udana i izvanbračni partner/partnerica. Preostale tri kategorije grupirane su u binarnu varijablu »razvedeni/udovci«.

Važan prediktor ishoda na tržištu rada može biti ljudski kapital pojedinca, za što se $u$ analizi upotrebljava podatak o najvišemu dosegnutom stupnju obrazovanja ispitanika. Anketa o radnoj snazi klasificira te stupnjeve sukladno Međunarodnoj standardnoj klasifikaciji obrazovanja. Budući da se obrazovni sustav izmijenio uvođenjem Bolonjskog procesa, kategorije stupnjeva obrazovanja donekle su se izmijenile. Za potrebe empirijske analize uvedena su tri agregatna stupnja: osnovnoškolsko obrazovanje, ${ }^{8}$ srednjoškolsko obrazovanje ${ }^{9}$ i visoko obrazovanje, koje obuhvaća sve ostale stupnjeve obrazovanja.

8 Odgovara sljedećim kategorijama iz upitnika Ankete o radnoj snazi 2006.: bez škole, 1 - 3 razreda osnovne škole, 4 - 7 razreda osnovne škole i osnovna škola. Za podatke iz 2012. to se odnosi na sljedeće kategorije: bez škole, nezavršena osnovna škola i osnovna škola.

9 Odgovara sljedećim kategorijama upitnika Ankete o radnoj snazi 2006.: škole za obrtnička i industrijska zanimanja i škole za KV- i VKV-radnike, tehničke, ekonomske, medicinske i slične srednje škole te gimnazije. Za podatke iz 2012. to se odnosi na sljedeće kategorije: industrijske i obrtničke strukovne škole, škole za zanimanja u trajanju od jedne godine; industrijske i obrtničke strukovne škole, škole za zanimanja u trajanju od dvije godine, industrijske i obrtničke strukovne škole, škole za zanimanja u trajanju od tri godine, tehničke i srodne strukovne škole, škole za zanimanja u trajanju od četiri godine i više te gimnazije. 
U različitim sredinama mogu prevladavati različiti uvjeti na tržištu rada, na primjer veća ili manja potražnja za radom. U analizi se razmatralo je li posrijedi urbano ili ruralno područje. Binarna varijabla »urbano« poprima vrijednost 1 ako ispitanik živi u gradskom ili prigradskom naselju, a vrijednost 0 ako živi u seoskom naselju ili kući izvan naselja.

Važna je i razlika po zanimanjima, koja zbog procesa restrukturiranja u Hrvatskoj, posebno tijekom krize, mogu generirati »viškove« koji se manifestiraju u povećanom broju nezaposlenih. Varijable koje opisuju zanimanje usklađene su s Nacionalnom klasifikacijom zanimanja. ${ }^{10} \mathrm{U}$ slučaju zaposlenih riječ je o zanimanju u vrijeme anketiranja, dok se kod nezaposlenih navodi zanimanje prethodnog posla ako su bili zaposleni. U slučaju neaktivnih pitanje zanimanja relativno je neprecizno definirano. Naime neaktivne osobe mogu imati iskustvo na tržištu rada, ali su se možda povukle iz aktivnog traženja posla. To može biti posljedica učinka obeshrabrenog radnika, koji naročito može biti izražen tijekom krize, no istodobno je moguće da neaktivne osobe nisu nikada ni tražile posao.

Podaci pokazuju da postoje određene razlike u strukturi uzorka u dvije analizirane godine. Prosječna starost doseljenih osoba veća je u 2012. te su u većoj mjeri zastupljene u urbanim naseljima. U strukturi podjednako i zaposlenih i nezaposlenih dominira srednjoškolsko obrazovanje. No najveće relativne promjene zabilježene su u strukturi zanimanja. U 2007. relativno najveći broj doseljenih nalazio se u zanimanjima u obrtu, dok u 2012. uslužna zanimanja, ali i stručnjaci imaju visoke udjele u strukturi zaposlenih. U strukturi nezaposlenih doseljenih osoba značajno se povećao udio jednostavnih zanimanja, zanimanja u obrtu i rukovatelja postrojenjima.

\section{PREDIKTORI NEZAPOSLENOSTI U ODNOSU NA ZAPOSLENOST DOSELJENIH U HRVATSKU}

Uzorak pokazuje relativno veliki udio nezaposlenih među doseljenim osobama. Potrebno je naglasiti da temeljem raspoloživih podataka ne možemo tvrditi da je moguće ocijeniti kolika je relativna stopa nezaposlenosti doseljenih osoba u odnosu na domicilno stanovništvo jer sam uzorak Ankete o radnoj snazi nije oblikovan na način koji bi omogućio dobivanje dovoljno pouzdanog odgovora na to pitanje. Ipak, podaci omogućuju ispitivanje u kojoj se mjeri određene karakteristike samih osoba - koje se uobičajeno smatraju relevantnima za ishode na tržištu rada - mogu identificirati kao prediktori određenog statusa doseljenih. Za empirijsku ocjenu odabran je

10 Posljednju važeću vidjeti na web-stranici Državnog zavoda za statistiku http:// www.dzs.hr/Hrv/important/Nomen/NKZ2010/NKZ_2010.pdf (18. 01. 2016.). 
model probit, a primijenjen je na istovjetni skup podataka u 2007. i 2012. kako bi se usporedbom dobivenih ocjena omogućila diskusija o tome je li došlo do promjena. Metoda probit ${ }^{11}$ prikladna je kada je zavisna varijabla binarna. U konkretnom slučaju zavisna varijabla poprima vrijednost 1 ako je osoba nezaposlena. Ocijenjeni su odgovarajući modeli temeljem kojih možemo vidjeti koje su varijable statistički značajni prediktori pojedinog statusa. Temeljem istog modela prikazan je i granični učinak. Budući da su sve objašnjavajuće varijable binarne, usporedbom graničnih učinaka možemo identificirati varijable s većim učinkom na zavisnu varijablu.

Prije ocjene modela probit, s obzirom na deskriptivnu statistiku, provedene su određene korekcije. Na primjer iz uzorka su isključene osobe s vojnim zanimanjima jer ih je relativno malo u uzorku. Također su iz razmatranja isključene osobe s nepoznatim zanimanjem jer ne pridonose zaključivanju. Iako podaci pokazuju da postoji relativno veliki udio nezaposlenih osoba koje nemaju radno iskustvo, ta činjenica savršeno je korelirana sa statusom nezaposlenosti. Zato osobe koje prvi put traže posao nisu uključene u empirijsku ocjenu prediktorâ statusa nezaposlenosti. Rezultati procjene navedeni su u tablici 2.

Ocijenjeni model ima relativno dobra statistička svojstva, što se može vidjeti iz dijagnostičkih pokazatelja koji opisuju karakteristike modela. Sve su varijable zajednički statistički značajne (Waldova statistika), stopa predviđanja relativno je dobra, a modeli u određenoj mjeri ipak mogu razvrstati prema identificiranim karakteristikama i nezaposlene i zaposlene, što ponekad kod nebalansiranih uzoraka nije slučaj (Greene, 2000). Prema ovoj posljednjoj karakteristici može se vidjeti da ocijenjeni model za 2012. u većoj mjeri može sukladno prediktorima identificirati nezaposlenu osobu, iako je ukupna stopa predviđanja niža nego kod modela ocijenjenog za 2007.

Promotrit ćemo prvo detaljnije rezultate identificiranja prediktora za 2007. (pretkriznu) godinu. Za doseljene u Hrvatsku statistički značajni prediktori statusa nezaposlenosti $u$ odnosu na status zaposlenosti redoslijedom svoga graničnog učinka bili su:

- pozitivni prediktori: uslužna zanimanja i osobe starije od 55 godina (u odnosu na dobnu skupinu 35 - 44)

- negativni prediktori: poljoprivredna zanimanja i muški spol.

Iz toga se može zaključiti da je među doseljenima u Hrvatsku relativno izloženija nezaposlenosti bila starija osoba ženskog spola te osoba čije je zanimanje u uslužnoj djelatnosti.

${ }^{11}$ Za osnovne informacije o modelima probit vidjeti na primjer Kmenta (1997). 
U 2012. skupina prediktora promijenila se, te su statistički značajni prediktori za status nezaposlenosti redoslijedom svojih graničnih učinaka bili sljedeći:

- pozitivni prediktori: jednostavna zanimanja, rukovatelji postrojenjima, osobe u dobi 15 - 24 godine (u odnosu na dobnu skupinu $35-44$ ), zanimanja u obrtu, uslužna zanimanja te osobe starije od 55 godina ( $u$ odnosu na referentnu skupinu)

- negativni prediktori: poljoprivrednici te osobe koje žive u urbanim sredinama.

Može se primijetiti da je u 2012. u većoj mjeri do izražaja došlo zanimanje osoba, što je vjerojatno u izravnoj vezi s činjenicom da zbog smanjenja potražnje za radnom snagom i zatvaranja pojedinih poduzeća dolazi do velikih viškova radne snage $u$ pojedinim zanimanjima. Također, dob postaje značajna varijabla, na što upućuju i druga istraživanja o kretanjima na hrvatskom tržištu rada (Matković, 2008).

Usporedbe radi, istovjetna analiza provedena je i za domicilnu skupinu. ${ }^{12}$ Budući da je riječ o znatno većem uzorku, logično je očekivati da će veći broj varijabli biti statistički značajan pri analizi domicilnog stanovništva. Stoga nije preporučljivo izravno uspoređivati značajnost pojedinih varijabli, ali moguće je diskutirati jesu li iste varijable statistički značajni pozitivni ili negativni prediktori nezaposlenosti domicilnog stanovništva. Analiza je pokazala da su navedeni prediktori u 2007. istog predznaka i u domicilnoj populaciji. Takav je slučaj i s podacima za 2012., kada sve varijable imaju isti predznak kao i kod doseljenog stanovništva, osim činjenice da dob od 15 do 24 godine nije statistički značajna za domicilno stanovništvo.

No za domicilnu populaciju pozitivni prediktori nezaposlenosti 2007. bili su i dob u dobnoj skupini 45 - 54, osnovno obrazovanje (u odnosu na srednjoškolsko) te veći broj zanimanja. U 2012. iste dobne skupine imaju veću vjerojatnost nezaposlenosti kao i 2007., ali i dobna skupina 25 - 34 postaje ona s većim rizikom od nezaposlenosti kod domicilnog stanovništva.

Analiza je pokazala da tradicionalne varijable prediktorâ statusa na tržištu rada jesu relevantne za doseljene u Hrvatsku. No još je važnije primijetiti da se prediktori tijekom vremena mijenjaju. Drugim riječima, učinci krize zamjetni su ne samo na ukupnim indikatorima kao što je stopa nezaposlenosti već i u strukturnim individualnim karakteristikama sudionika na tržištu rada.

12 Rezultati nisu navedeni zbog prostornog ograničenja, ali su dostupni na zahtjev od autorice. 


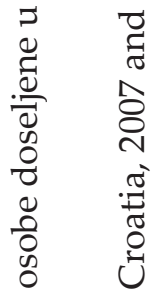

ก

ํํㅇ 节

$\therefore$.

今ิ घี

กิ

का पे

竞 $\quad \frac{0}{\infty}$

กิ

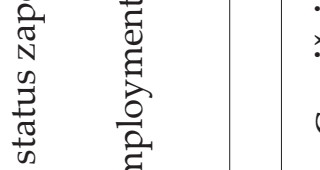

突

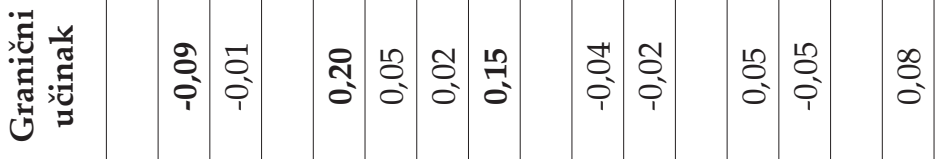

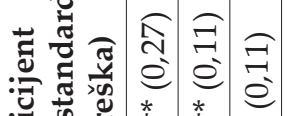

તิ

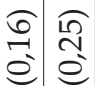

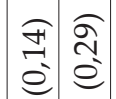

శֶ)

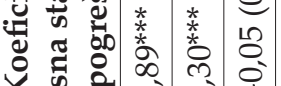

*

$\begin{array}{lll}\text { m } & 10 \\ 0 & 0 \\ 0 & 0\end{array}$

\begin{tabular}{ll|l}
1 & $\infty$ \\
0 & - \\
0 & 1
\end{tabular}

芯

ฮ

늉

ว

ڤิ

$=\quad \frac{ \pm}{0}$

i

$\frac{0}{0} \quad \frac{\pi}{2}$

हैं क

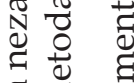

ब है है

䒕 $\frac{0}{0} \widehat{0}$

की

क 3 ह

.

퓨.

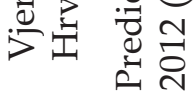

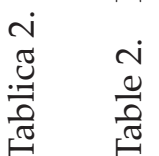

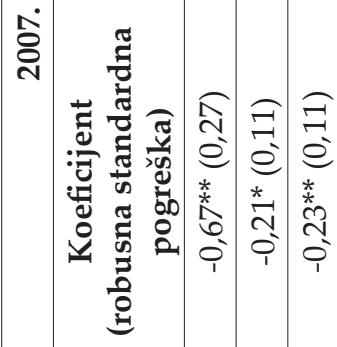

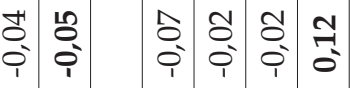

\begin{tabular}{ll|l}
10 & 4 \\
0 & 0 \\
0 & 0
\end{tabular}

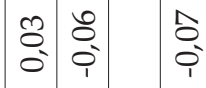

氞节

\section{1}

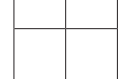

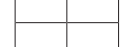
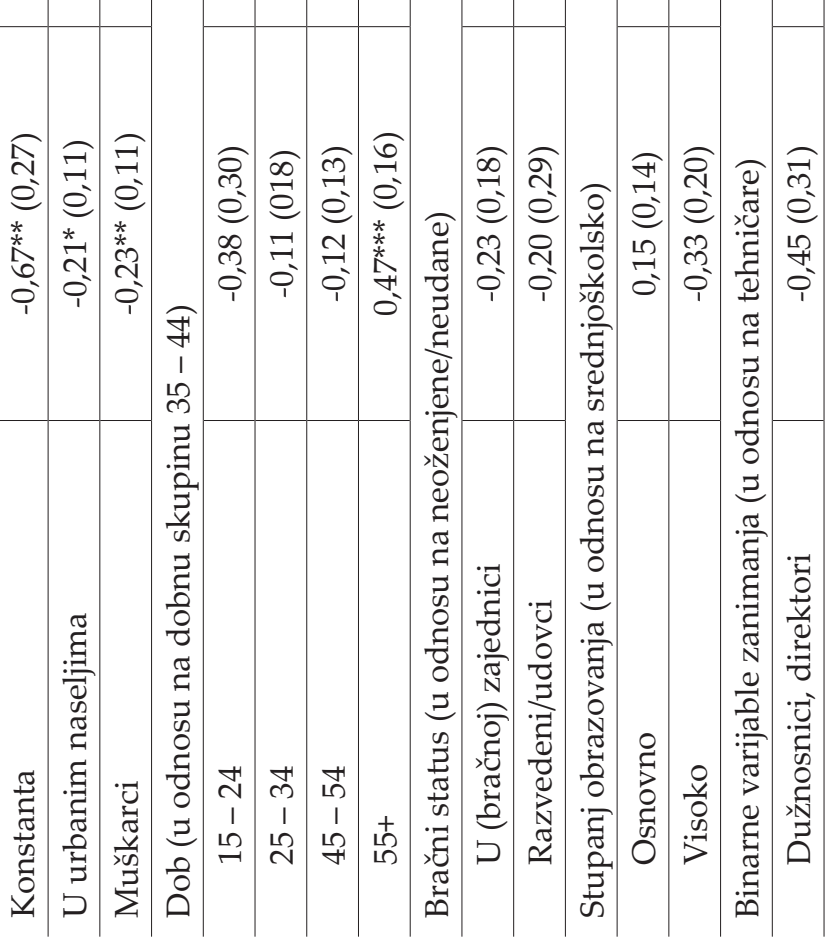
:

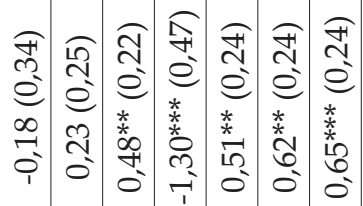

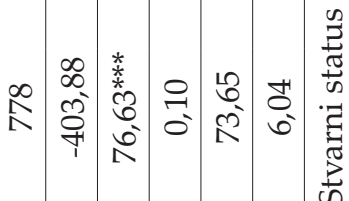

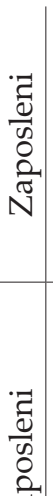

$1 \quad \frac{\pi}{2} \frac{\pi}{2} \frac{\pi}{2}$

S.

…ㄹ.:

ज्ञ

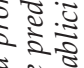

$5 \%$

홍ㄱㄹ

5.

\&

.

ㄷำ

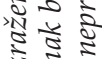

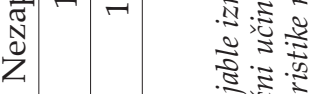

离 $\frac{3}{3}$

के

ริำ

高竞

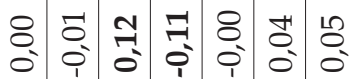

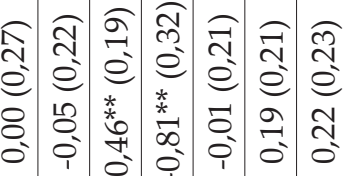

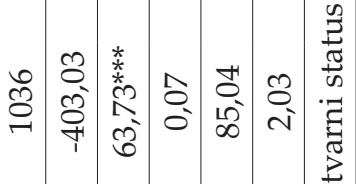

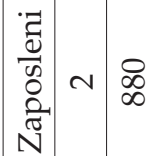

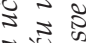

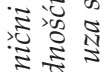

ก)

곤

속졸

के के

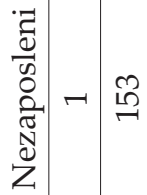

ㅇ.

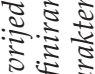

i这章 咅

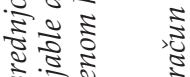

글

5 5

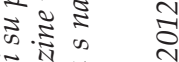

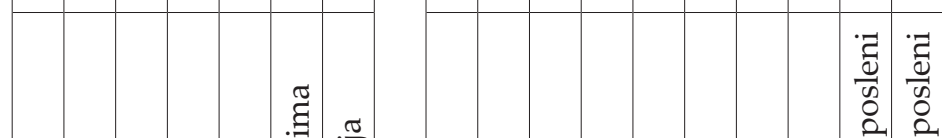

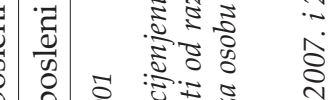

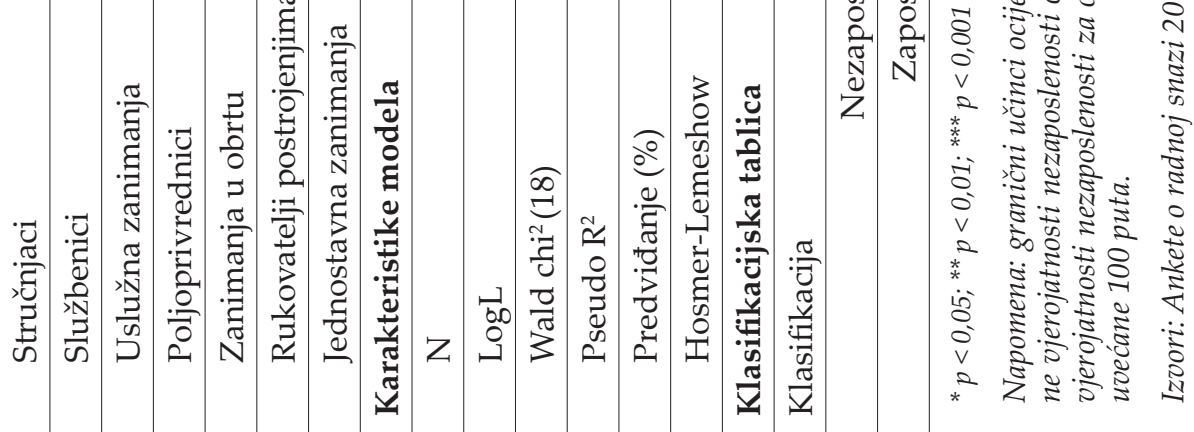




\section{PREDIKTORI DUGOTRAJNE NEZAPOSLENOSTI DOSELJENIH U HRVATSKU}

Drugi važan aspekti nezaposlenosti koji se analizira u ovom radu njezino je trajanje. Naime dugotrajna nezaposlenost u Hrvatskoj je izuzetno visoka (Bejaković, 2013), a jedna je od njezinih značajnih posljedica na razini pojedinca gubitak vještina i kompetencija, što otežava zapošljavanje. Time raširena dugotrajna nezaposlenost pridonosi očuvanju visokih stopa nezaposlenosti na nekom tržištu rada i otežava rješavanje tog pitanja. Ispitujemo u kojoj je mjeri taj aspekt raširen u populaciji osoba doseljenih u Hrvatsku.

Da bismo mogli diskutirati o učincima dugotrajne nezaposlenosti, najprije moramo definirati kada se nezaposlenost može smatrati dugotrajnom. Ako je riječ o tržištu rada na kojem postoji relativno velika mobilnost, tada se i šestomjesečna nezaposlenost može smatrati dugotrajnom. No hrvatsko tržište rada općenito nema tu karakteristiku. Stoga smo, slijedom prethodnih istraživanja (Botrić, 2009), kao granicu dugotrajne nezaposlenosti definirali nezaposlenost dulju od godine dana (što je u skladu s definicijom koju primjenjuje Eurostat ${ }^{13}$ ), ali i kao iznimno dugotrajnu onu koja traje dulje od dvije godine. Kao kratkotrajnu nezaposlenost odabrali smo nezaposlenost do godine dana, unatoč činjenici da je riječ o razmjerno dugom razdoblju traženja posla.

$\mathrm{U}$ tablici 3 također se mogu vidjeti zanimljive promjene između dvije analizirane godine. Može se primijetiti da se značajno povećao udio prijavljenih na Hrvatski zavod za zapošljavanje, kao i udio korisnika naknada za nezaposlenost, pri čemu se oba podatka mogu dovesti u izravnu vezu s učincima krize. Ti udjeli rastu podjednako i za kratkotrajno i za dugotrajno nezaposlene.

Podaci pokazuju da i kod kratkotrajno i kod dugotrajno nezaposlenih u strukturi prevladavaju osobe sa srednjoškolskim obrazovanjem. No udio osoba koje imaju samo osnovni stupanj obrazovanja visok je za dugotrajno nezaposlene. Također se može primijetiti da su u uzorku iz 2012. doseljene nezaposlene osobe $u$ prosjeku nešto starije te da je istovremeno manji udio nezaposlenih bez radnog iskustva. Iako na temelju prikazanih podataka ne možemo eksplicitno utvrditi vezu, posredno takvu strukturu možemo dovesti u vezu s anegdotalnim dokazima o iseljavanju mlađih dobnih skupina iz Hrvatske tijekom razdoblja krize.

13 Definicija se nalazi na poveznici http://ec.europa.eu/eurostat/web/gdp-and-beyond/quality-of-life/long-term-unemployment-rate. Može se vidjeti da Hrvatska pripada skupini zemalja s izrazito visokim udjelom dugotrajne u ukupnoj nezaposlenosti. 
Tablica 3. Kratkotrajna i dugotrajna nezaposlenost doseljenih u Hrvatsku 2007. i 2012.

Table 3. Short term and long term unemployment of immigrants in Croatia, 2007 and 2012

\begin{tabular}{|c|c|c|c|c|c|c|}
\hline & \multicolumn{3}{|c|}{2007.} & \multicolumn{3}{|c|}{2012.} \\
\hline & \multicolumn{6}{|c|}{ Trajanje nezaposlenosti } \\
\hline & $\begin{array}{l}<1 \\
\text { godine }\end{array}$ & $\begin{array}{l}\text { Između } \\
1 \text { i } 2 \\
\text { godine }\end{array}$ & $\begin{array}{c}>2 \\
\text { godine }\end{array}$ & $\begin{array}{c}<1 \\
\text { godine }\end{array}$ & $\begin{array}{l}\text { Između } \\
1 \text { i } 2 \\
\text { godine }\end{array}$ & $\begin{array}{c}>2 \\
\text { godine }\end{array}$ \\
\hline $\begin{array}{l}\text { Prosječna dob } \\
\text { (godine) }\end{array}$ & 35,70 & 37,35 & 42,85 & 40,01 & 37,15 & 44,57 \\
\hline $\begin{array}{l}\text { Duljina boravka } \\
\text { u Hrvatskoj } \\
\text { (godine) }\end{array}$ & 17,16 & 22,94 & 22,08 & 23,88 & 22,41 & 27,38 \\
\hline \multicolumn{7}{|l|}{ Spol (\%) } \\
\hline Muškarci & 50,51 & 51,61 & 44,85 & 58,97 & 56,10 & 46,95 \\
\hline \multicolumn{7}{|l|}{ Bračni status (\%) } \\
\hline $\begin{array}{l}\text { U (bračnoj) } \\
\text { zajednici }\end{array}$ & 61,62 & 51,61 & 67,88 & 64,10 & 51,22 & 65,24 \\
\hline Razvedeni/udovci & 2,02 & 3,22 & 7,27 & 6,41 & 4,88 & 5,49 \\
\hline \multicolumn{7}{|c|}{ Područje stanovanja (\%) } \\
\hline $\begin{array}{l}\text { U urbanim } \\
\text { područjima }\end{array}$ & 46,46 & 54,84 & 48,48 & 44,87 & 63,41 & 54,88 \\
\hline $\begin{array}{l}\text { Prijavljeni na } \\
\text { HZZ (\%) }\end{array}$ & 55,56 & 61,29 & 55,15 & 70,51 & 70,73 & 61,59 \\
\hline $\begin{array}{l}\text { Korisnici naknada } \\
\text { za nezaposlenost } \\
(\%)\end{array}$ & 7,07 & 9,68 & 5,45 & 17,95 & 12,19 & 9,15 \\
\hline \multicolumn{7}{|c|}{ Stupanj obrazovanja (\%) } \\
\hline Osnovno & 17,17 & 16,13 & 40,00 & 23,08 & 19,51 & 29,27 \\
\hline Srednje & 74,75 & 70,97 & 52,12 & 69,23 & 73,17 & 63,41 \\
\hline Visoko & 8,08 & 12,90 & 7,87 & 7,69 & 7,32 & 7,32 \\
\hline \multicolumn{7}{|l|}{ Zanimanja (\%) } \\
\hline $\begin{array}{l}\text { Dužnosnici, } \\
\text { direktori }\end{array}$ & 1,01 & - & 1,21 & 1,28 & 4,88 & 3,05 \\
\hline Stručnjaci & 2,02 & 6,45 & 2,42 & 2,56 & - & 4,27 \\
\hline Tehničari & 4,04 & 9,68 & 4,85 & 3,85 & 7,32 & 2,44 \\
\hline
\end{tabular}




\begin{tabular}{l|c|c|c|c|c|c}
\hline \multirow{2}{*}{} & \multicolumn{4}{|c|}{$\mathbf{2 0 0 7 .}$} & \multicolumn{3}{c}{2012.} \\
\cline { 2 - 7 } & $\begin{array}{c}\text { Trajanje nezaposlenosti } \\
\text { godine }\end{array}$ & $\begin{array}{c}\text { Između } \\
\mathbf{1} \text { i } \mathbf{2} \\
\text { godine }\end{array}$ & $\begin{array}{c}>\mathbf{2} \\
\text { godine }\end{array}$ & $\begin{array}{c}<\mathbf{1} \\
\text { godine }\end{array}$ & $\begin{array}{c}\text { Između } \\
\mathbf{1} \text { i } \mathbf{g} \\
\text { godine }\end{array}$ & $\begin{array}{c}>\mathbf{2} \\
\text { godine }\end{array}$ \\
\cline { 2 - 7 } & - & 6,45 & 6,67 & 3,85 & 12,19 & 4,27 \\
\hline Službenici & 11,11 & 9,68 & 16,36 & 19,23 & 9,76 & 18,29 \\
\hline Uslužna zanimanja & 1,01 & 3,23 & 1,21 & - & - & 0,61 \\
\hline Poljoprivrednici & 9,09 & 6,45 & 6,67 & 10,26 & 12,19 & 13,41 \\
\hline Zanimanja u obrtu & 5,05 & 3,23 & 10,91 & 15,38 & 9,76 & 9,76 \\
\hline $\begin{array}{l}\text { Rukovatelji } \\
\text { postrojenjima }\end{array}$ & 10,10 & 3,23 & 7,88 & 20,51 & 17,07 & 12,80 \\
\hline $\begin{array}{l}\text { Jednostavna } \\
\text { zanimanja }\end{array}$ & 56,57 & 51,61 & 40,00 & 23,08 & 21,95 & 29,88 \\
\hline $\begin{array}{l}\text { Bez radnog } \\
\text { iskustva }\end{array}$ & $\mathbf{9 9}$ & $\mathbf{3 1}$ & $\mathbf{1 6 5}$ & $\mathbf{7 8}$ & $\mathbf{4 1}$ & $\mathbf{1 6 4}$ \\
\hline $\begin{array}{l}\text { Veličina uzorka } \\
\text { (N) }\end{array}$ & & & &
\end{tabular}

Napomena: - označuje mali broj opažanja

Izvori: Anketa o radnoj snazi 2007. i 2012., izračun autora

Jedna je od zanimljivih varijabli duljina boravka u Hrvatskoj te njezina veza s duljinom nezaposlenosti. Drugim riječima: pronalaze li osobe koje dolaze u Hrvatsku relativno brzo posao? Stoga smo razmotrili prosječni broj godina boravka u Hrvatskoj za populaciju kratkotrajno i dugotrajno nezaposlenih. Može se vidjeti da je prosječna duljina boravka osoba u Hrvatskoj 2012. značajno veća od one 2007. To znači da nezaposlenost dodatno pogađa i osobe koje su već dulje u Hrvatskoj, a ne samo nedavno doseljene. Potrebno je naglasiti da u ovom slučaju postoji relativno velik postotak nepostojećih odgovora na pitanje iz ARS-a 2007., pa navedene podatke valja promatrati samo kao ilustraciju.

Na temelju tako definiranog uzorka provedena je analiza prediktorâ dugotrajne nezaposlenosti u odnosu na kratkotrajnu. Kao i u prethodnoj analizi prediktorâ statusa nezaposlenosti ocijenjen je model probit. Iz cjelokupnog uzorka isključeni su nezaposleni koji su imali nepoznato prethodno zanimanje i nezaposlene osobe koje su bile u vojnim zanimanjima. Zbog relativno male zastupljenosti u uzorku isključene su i osobe koje su imale prethodno zaposlenje u zanimanju »dužnosnici i direktori«. Rezultati provedene analize navedeni su u tablici 4 . 
Ocijenjeni model ima relativno dobra statistička svojstva. Sve su varijable zajednički statistički značajne (što se može vidjeti iz Waldove statistike), stopa predviđanja relativno je dobra, a modeli mogu razvrstati prema identificiranim karakteristikama i dugotrajno i kratkotrajno nezaposlene, i to u većoj mjeri nego oni navedeni $\mathrm{u}$ tablici 2.

Za doseljene u Hrvatsku statistički značajni prediktori dugotrajne u odnosu na kratkotrajnu nezaposlenost u 2007. redoslijedom svoga graničnog učinka bili su:

- pozitivni prediktori: osnovno obrazovanje (u odnosu na srednjoškolsko) te dvije dobne skupine, iznad 55 i između 45 i 54 godine (u odnosu na dobnu skupinu 35 -44).

Može se primijetiti određena sličnost s prediktorima statusa nezaposlenosti u odnosu na status zaposlenosti. Dobna skupina iznad 55 godina ne samo da ima veću vjerojatnost nezaposlenosti već je i u slučaju nezaposlenosti veća vjerojatnost da će biti dugotrajno nezaposlena. $\mathrm{S}$ obzirom na negativne demografske trendove pitanju zapošljavanja starijih građana i smanjenju rizika od nezaposlenosti i dugotrajne nezaposlenosti potrebno je u budućnosti posvetiti veću pozornost.

U 2012. skupina prediktora donekle se promijenila, te su statistički značajni prediktori za status dugotrajne nezaposlenosti redoslijedom graničnog učinka bili sljedeći:

- pozitivni prediktori: osobe bez radnog iskustva i osobe starije od 55 godina (u odnosu na referentnu skupinu)

- negativni prediktori: dobna skupina 15 - 24 i 25 - 34 (u odnosu na referentnu skupinu), život nakon i u (bračnoj) zajednici te muški spol.

U 2012. prediktori statusa dugotrajne nezaposlenosti nisu toliko slični prediktorima statusa nezaposlenosti, što donekle možemo povezati s činjenicom da se u promatranom razdoblju struktura nezaposlenih značajno promijenila. Na primjer iako mlađe dobne skupine imaju relativno veću vjerojatnost nezaposlenosti, rizik od njihove dugotrajne nezaposlenosti prema podacima je relativno manji. 


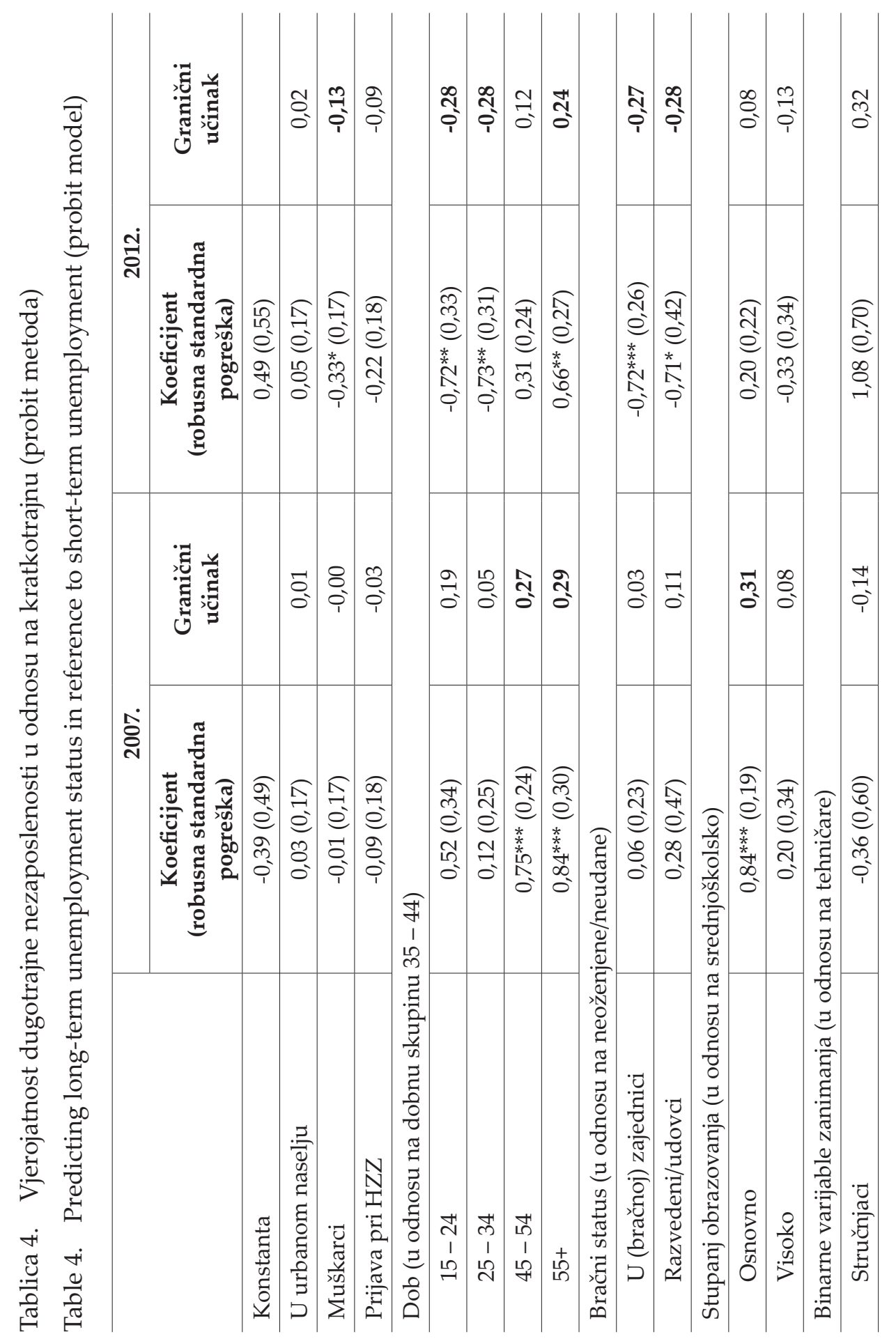




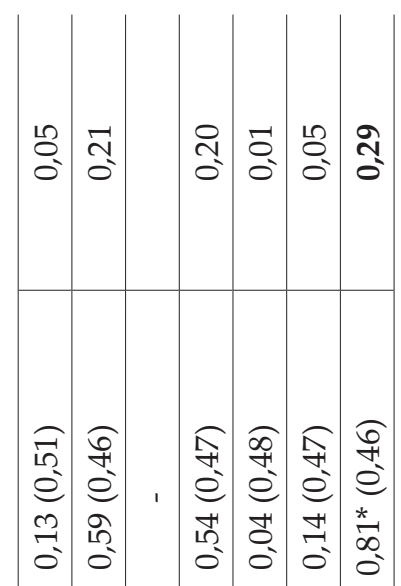

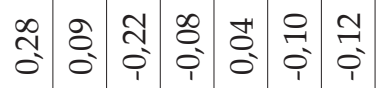

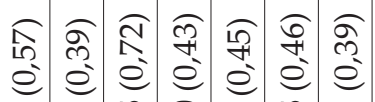

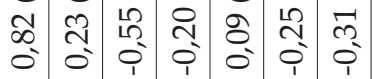

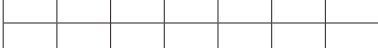

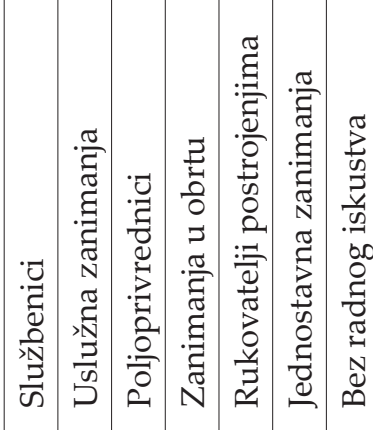

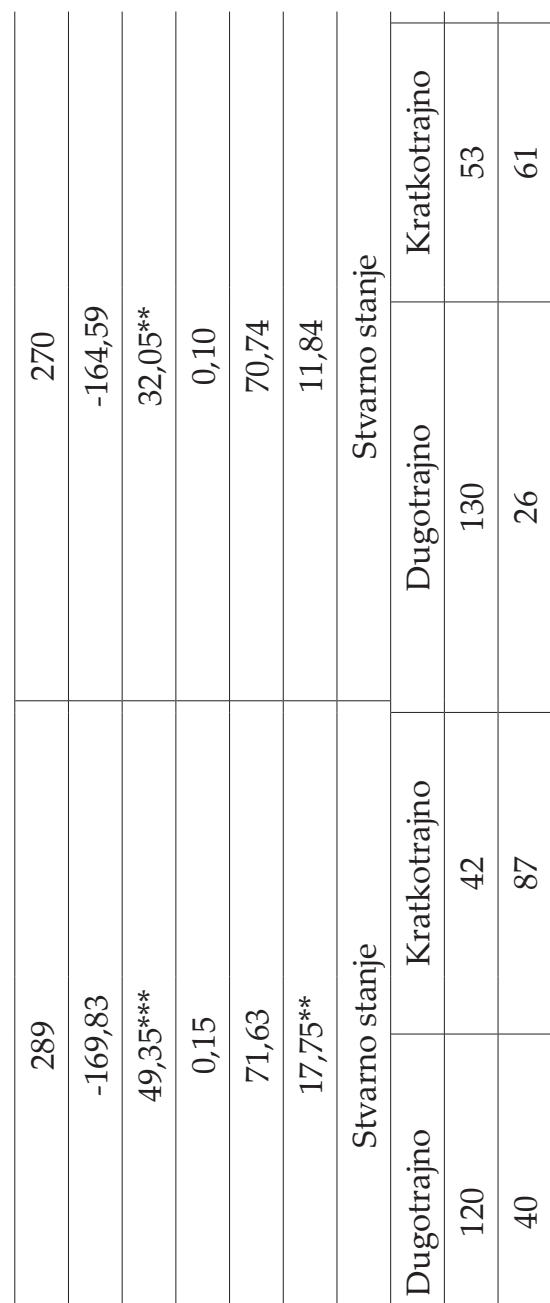

:

कर $\frac{\sqrt{2}}{\sqrt{3}}$

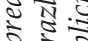

$\frac{5}{2} \cdot \frac{5}{2} \frac{}{2}$

군

$\frac{1}{5} \cdot \frac{5}{5}$

इ $2: \frac{2}{2}$

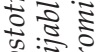

ह ई

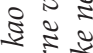

$\therefore \frac{2}{2}$

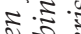

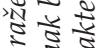

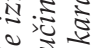

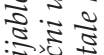

दे क

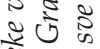

ฐ.

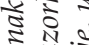

於

$\therefore$. 3

깅

年毒年

य.

골ำ

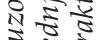

जक के

ङ

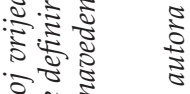

욜 का

के $\frac{7}{5} \frac{5}{0}$.

대 50 .

․ำ

का

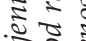

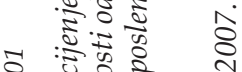

8 .

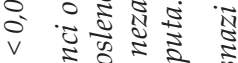

2 额

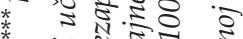
में

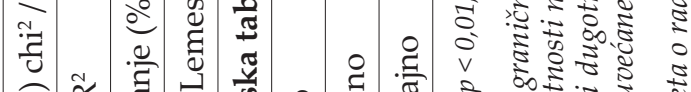


Ako se usporede prediktori 2007. i 2012., očito je da je značajna promjena zabilježena kod osoba koje prvi put traže posao. U njihovu je slučaju učinak krize otežao pronalaženje zaposlenja, čak i do te mjere da nedostatak iskustva postaje pozitivni prediktor za dugotrajnu nezaposlenost.

I u ovom je slučaju provedena istovjetna analiza za domicilno stanovništvo ${ }^{14}$ koja je pokazala da su u 2007. predznaci varijabli za domicilno stanovništvo isti kao i kod doseljenih. No uloga obrazovanja kod domicilnog je stanovništva veća, jer osobe s nižim stupnjem obrazovanja imaju veću vjerojatnost dugotrajne nezaposlenosti, dok je u osoba s visokim stupnjem obrazovanja ta vjerojatnost niža. U 2012. zabilježene su određene promjene. Za domicilno stanovništvo obrazovanje je relevantna karakteristika, dok nedostatak radnog iskustva nije značajni prediktor za dugotrajnu nezaposlenost. Drugim riječima, čini se da pod utjecajem krize postoje različita iskustva domicilnog i doseljenog stanovništva na hrvatskom tržištu rada.

\section{ZAKLJUČAK}

U radu se ispituju prediktori statusa nezaposlenosti (u odnosu na status zaposlenosti) i dugotrajne nezaposlenosti u odnosu na kratkotrajnu za skupinu doseljenih u Hrvatsku. Analiza je pokazala da su čimbenici koji se uobičajeno smatraju relevantnima za predviđanje ishoda na tržištu rada značajni i u odnosu na tu skupinu. Također, usporedbe s domicilnim stanovništvom pokazale su da prediktori doseljenih osoba s vremenom postaju različiti.

U empirijskoj analizi razmotrene su dvije godine te se pokazalo da su se prediktori u 2012. značajno promijenili u odnosu na 2007. i u smislu statističke značajnosti, ali čak i u predznaku. Budući da su tijekom tog razdoblja zabilježene značajne promjene na hrvatskom tržištu rada, dio obrazloženja sigurno se može pripisati posljedicama ekonomske krize. Potrebna su dodatna istraživanja kako bi se ta tvrdnja doista i potvrdila.

Imajući u vidu potrebu aktivnoga kreiranja budućih imigracijskih politika, relevantnije je promotriti nalaze istraživanja za 2012. Podaci su pokazali da određena zanimanja u 2012. (jednostavna zanimanja, uslužna zanimanja, zanimanja u obrtu i rukovatelji postrojenjima) postaju značajni prediktori statusa nezaposlenosti. Takvi nalazi upućuju da je nužno identificirati djelatnosti koje će kreirati potražnju za radnom snagom te precizno identificirati koje su to kompetencije i vještine koje doseljena osoba mora imati kako bi se što je moguće lakše uključila u tržište rada. Nadalje, rezultati su

14 Rezultati analize dostupni su od autorice na zahtjev. 
također pokazali da veću vjerojatnost nezaposlenosti imaju mladi i starije osobe. Takvi su trendovi prepoznati na europskoj razini (Chaloff, Dumont i Liebig, 2012), gdje strateški dokumenti nastoje definirati posebna rješenja za smanjivanje rizika nezaposlenosti upravo tih dobnih skupina. No postoje i određene specifičnosti hrvatskog tržišta rada. Iako su istraživanja u drugim zemljama pokazala da je kriza u većoj mjeri utjecala na zapošljavanje muškaraca, takvi nalazi nisu identificirani u slučaju doseljenih u Hrvatsku.

Drugi je segment analiza trajanja nezaposlenosti, koja je pokazala da doseljene osobe koje nemaju radno iskustvo i starije dobne skupine imaju tijekom gospodarske krize veću vjerojatnost za dugotrajnu nezaposlenost. Rezultati su istovremeno pokazali da mlađe osobe imaju manju vjerojatnost dugotrajne nezaposlenosti. Je li ovaj posljednji rezultat posljedica relativno većeg iseljavanja mladih iz Hrvatske, tek valja istražiti.

Podaci su potvrdili da su neke podskupine doseljenog stanovništva više nego druge izložene problemima tržišta rada koje je pod utjecajem krize. Bez osmišljavanja načina uključivanja doseljenih osoba na hrvatsko tržište rada aktivna imigracijska politika neće dati odgovarajuće rezultate. A bez aktivne imigracijske politike, imajući $u$ vidu procese demografskog starenja, možemo očekivati brojne fiskalne probleme u hrvatskom gospodarstvu.

Zahvale: Rana verzija ovog rada prezentirana je na konferenciji Migracije i etničnost na početku 21. stoljeća: povodom 30 godina izlaženja časopisa Migracijske i etničke teme (1985.-2015.) održanoj u Zagrebu 26. veljače 2015. u organizaciji Instituta za migracije i narodnosti. Autorica zahvaljuje sudionicima konferencije na poticajima za rad. Također zahvaljuje anonimnim recenzentima na korisnim sugestijama.

\section{LITERATURA}

Arai, M. i Vilhelmsson, R. (2004). Unemployment-Risk Differentials between Immigrant and Native Workers in Sweden, Industrial Relations, 43 (3): 690-698, doi: 10.1111/j.00198676.2004.00355.x.

Azmat, G., Güell, M. i Manning, A. (2006). Gender Gaps in Unemployment Rates in OECD Countries, Journal of Labor Economics, 24 (1): 1-37, doi: 10.1086/497817.

Bejaković, P. (2013). Opasnost od dugotrajne nezaposlenosti u Hrvatskoj, Radno pravo, 13 (9): 72-81. 
Bernardi F., Garrido L. i Miyar M. (2011). The Recent Fast Upsurge of Immigrants in Spain and Their Employment Patterns and Occupational Attainment, International Migration, 49 (1): 148-187, doi: 10.1111/j.1468-2435.2010.00610.x.

Bevelander, P. i Irastorza, N. (2014). Catching Up: The Labor Market Integration of New Immigrants in Sweden. Migration Policy Institute - International Labour Organization, http://www.migrationpolicy.org/research/catching-labor-marketoutcomes-new-immigrants-sweden (24. 01. 2016.).

Blackaby, D. H., Latreille, P. L., Murphy, P. D., O’Leary, N. C. i Sloane, P. J. (2007). An Analysis of Reservation Wages for the Economically Inactive, Economic Letters, 97 (1): 1-5, doi: 10.1016/j.econlet.2007.02.005.

Boeri, T. i Brücker H. (2005). Migration, Co-ordination Failures and EU Enlargement. Bonn: IZA (IZA Discussion Papers, 1600).

Borjas, G. J. (1985). Assimilation, Changes in Cohort Quality, and Earnings of Immigrants, Journal of Labor Economics, 3 (4): 463-489, doi: 10.1086/298065.

Botrić, V. (2009). Unemployed and long-term unemployed in Croatia: evidence from Labour Force Survey, Revija za socijalnu politiku, 16 (1): 25-44, doi: 10.3935/rsp. v16i1.807.

Botrić, V. (2015). Relative labour market outcomes of immigrants in Croatia, Economics and Sociology, 8 (3): 197-214, doi: 10.14254/2071-789x.2015/8-3/15.

Brown, S. i Taylor, K. (2008). Reservation Wages, Expected Wages and Labour Market Outcomes: Analysis of Individual Level Panel data. Sheffield: University of Sheffield (Sheffield Economic Research Paper Series, SERP, 2008008), http://www.sheffield. ac.uk/economics/research/serps/articles/2008_08 (18. 01. 2016.).

Büchel F. i Frick J. R. (2005). Immigrants' Economic Performance across Europe - does Immigration Policy Matter?, Population Research and Policy Review, 24 (2): 175-212, doi: 10.1007/s11113-004-1370-4.

Cerveny, J. i van Ours, J. C. (2013). Unemployment of Non-western Immigrants in the Great Recession. Bonn: IZA (IZA Discussion Paper, 7598).

Chaloff, J., Dumont J.-C. i Liebig, T. (2012). The Impact of the Economic Crisis on Migration and Labour Market Outcomes of Immigrants in OECD Countries, CESIfo DICE Report, 10 (1): 39-47.

Christensen, B. (2001). The Determinants of Reservation Wages in Germany Does a Motivation Gap Exist?. Kiel: Kiel Institute of World Economics (Kiel Working Paper, 1024), http:// ftp.zew.de/pub/zew-docs/div/christensen.pdf (18. 01. 2016.).

Chiswick B. (1978). The Effect of Americanisation on the Earnings of Foreign-born Men, Journal of Political Economy, 86 (5): 897-921, doi: 10.1086/260717.

Davia, M. A.i Marcenaro-Gutiérrez,O.D. (2007). Exploring the Link between Employment Search Time and Reservation Wages in Southern Europe, Hacienda Pública Española / Revista de Economía Pública, 186 (3): 91-121, http://www.ief.es/documentos/recursos/ publicaciones/revistas/hac_pub/186_Exploring.pdf (18. 01. 2016.).

De Giorgi, G. i Pellizzari, M. (2009). Welfare Migration in Europe, Labour Economics, 16 (4): 353-363, doi: 10.1016/j.labeco.2009.01.005.

De la Rica, S., Glitz, A. i Ortega, F. (2013). Immigration in Europe: Trends, Policies and Empirical Evidence. Bonn: IZA (IZA Discussion Paper Series, 7778). 
De la Rica, S. i Polonyankina, T. (2013). The Impact of Immigration on Occupational Specialisation among Natives in Spain: Does the Business Cycle Matter?, Revista de Economía Aplicada, 21 (63): 51-74.

Drinkwater, S. i Robinson, C. (2011). Welfare Participation by Immigrants in the UK. Bonn: IZA (IZA Discussion Paper Series, 6144), http://ftp.iza.org/dp6144.pdf (18. 01. 2016.).

Dustmann, C., Glitz, A. i Vogel, T. (2010). Employment, Wages and the Economic Cycle: Differences between Immigrants and Natives, European Economic Review, 54 (1): 1-17, doi: 10.1016/j.euroecorev.2009.04.004.

European Commision (2011). Migrants in Europe: a Statistical Portrait of the First and Second Generation. Luxembourg: Publications Office of the European Union, doi: $10.2785 / 5318$.

Fullin G. i Reyneri E. (2011). Low Unemployment and Bad Jobs for New Immigrants in Italy, International Migration, 49 (1): 118-147, doi: 10.1111/j.1468-2435.2009.00594.x.

Greene, W. H. (2000). Econometric Analysis. New Jersey: Prentice Hall International.

Greenwood, M. i McDowell, J. (1986). The Factor Market Consequences of U.S. Immigration, Journal of Economic Literature, 24 (4): 1738-1772.

Harris, J. i Todaro, M. (1970). Migration, Unemployment and Development: A TwoSector Analysis, American Economic Review, 60 (1): 26-42.

Jean, S., Causa, O., Jimenez, M. i Wanner, I. (2010). Migration and labour market outcomes in OECD countries. OECD Journal: Economic Studies, 2010 (1), 1-34, doi: 10.1787/eco_studies-2010-5kmhf827kws6.

Jones, S. R. G. (1989). Reservation Wages and the Cost of Unemployment, Economica, 56 (222): 225-246, doi: 10.2307/2554041.

Kahanec, M. i Zaiceva, A. (2008). Labour Market Outcomes of Immigrants and Non-Citizens in the EU: An East-West comparison. Bonn: IZA (IZA Discussion Paper, 3420).

Kerovec, N. (2003). (Ne)jednakost žena na tržištu rada, Revija za socijalnu politiku, 10 (3): 263-282, doi: 10.3935/rsp.v10i3.105.

Kmenta, J. (1997). Počela ekonometrije. Zagreb: MATE.

Kogan I. (2011). New Immigrants, Old Disadvantage Patterns? Labour Market Integration of Recent Immigrants into Germany, International Migration, 49 (1): 91117, doi: 10.1111/j.1468-2435.2010.00609.x.

Kogan I. (2015). The role of immigration policies for immigrants' selection and economic success. Antwerp: Herman Deleeck Centre for Social Policy - University of Antwerp (ImPRovE Working Paper, 15/05).

Longhi, S., Nijkamp, P. i Poot, J. (2010). Joint impacts of immigration on wages and employment: review and meta-analysis, Journal of Geographical Systems, 12 (4): 355387, doi: 10.1007/s10109-010-0111-y.

Matković, T. (2008). Tko što radi? Dob i rod kao odrednice položaja na tržištu rada u Hrvatskoj, Revija za socijalnu politiku, 15 (3): 479-502, doi: 10.3935/rsp.v15i3.802.

Markaki, Y. (2014). Do Labour Market Conditions Shape Immigrant-Native Gaps in Employment Outcomes? A Comparison of 19 European Economies. Essex: Institute for Social and Economic Research, University of Essex (ISER Working Paper, 2014-41), https://www.iser.essex.ac.uk/research/publications/working-papers/iser/2014-41. pdf (24. 01. 2016.). 
Nannestad, P. (2007). Immigration and Welfare States: a Survey of 15 Years of Research, European Journal of Political Economy, 23 (2):512-532, doi: 10.1016/j.ejpoleco.2006.08.007.

Nestić, D., Rubil, I. i Tomić, I. (2015). Analiza razlika u plaćama između javnog sektora, poduzeća u državnom vlasništvu i privatnog sektora u Hrvatskoj 2000. - 2012., Privredna kretanja i ekonomska politika, 24 (1): 7-50.

Peracchi, F. i Depalo, D. (2006). Labor market outcomes of natives and immigrants: Evidence from the ECHP. Washington: The World Bank (Social Protection Discussion Paper, 0615), http://siteresources.worldbank.org/SOCIALPROTECTION/Resources/SPDiscussion-papers/Labor-Market-DP/0615.pdf (24.01.2016.).

Prasad, E. S. (2003). What Determines the Reservation Wages of Unemployed Workers? New Evidence from German Micro Data. Washington: International Monetary Fund (IMF Working Paper, WP03/4), doi: 10.5089/9781451842067.001.

Thapa, P. J. (2004). On the Risk of Unemployment: A Comparative Assessment of the Labour Market Success of Migrants in Australia, Australian Journal of Labour Economics, 7 (2): 199-229.

Todaro, M. (1969). A Model of Labor Migration and Urban Unemployement in Less Developed Countries, American Economic Review, 69: 486-499.

Unemployment Risk Factors in Estonia, Latvia and Lithuania. (2003). OECD, http:// www.oecd.org/dataoecd/28/55/2493996.pdf (18. 01. 2016.).

\section{IZVORI}

Anketa o radnoj snazi, Metodološke upute 71, Državni zavod za statistiku, Zagreb, 2013, http://www.dzs.hr.

Državni inspektorat (2013). Izvješće o radu Državnog inspektorata u 2012. godini, https://vlada.gov.hr/UserDocsImages//Sjednice/Arhiva//90.\%20-\%2020.pdf (18. 01. 2016.).

Ministarstvo unutarnjih poslova (2014). Strani državljani sa statusom odobrenog privremenog boravka na dan 31. 12. 2012., http://www.mup.hr/UserDocsImages/ Dokumenti/stranci/statistika/2013/strani_državljani_sa_statusom_odobrenog_ privremenog_boravka_31122012.pdf (22. 01. 2016.).

Ministarstvo unutarnjih poslova (2015). Državljani trećih država na odobrenom stalnom boravku na dan 31. 12. 2014., http://www.mup.hr/UserDocsImages/Dokumenti/ stranci/statistika/2015/statistika8.pdf (18. 01. 2016.).

Ministarstvo unutarnjih poslova (2015). Državljani trećih država s odobrenim privremenim boravkom na dan 31. 12. 2014., http://www.mup.hr/UserDocsImages/ Dokumenti/stranci/statistika/2015/statistika5.pdf (18. 01. 2016.).

Popis stanovništva, kućanstava i stanova 2011., Državni zavod za statistiku, Zagreb, http:// www.dzs.hr. 


\title{
Unemployment and Long-Term Unemployment of Immigrants in Croatia
}

\author{
Valerija Botrić
}

\section{SUMMARY}

Migration issues in Croatia have been mostly discussed in relation to the recent increase in emigration, in particular related to the emigration of young and highly educated persons. However, active migration policy should consider immigration dynamics as well. In the framework of long-term prospects of the Croatian labour market, and taking into consideration the advanced effects of the demographic aging process, the issue of active immigration policy is expected to become more important in the future.

The main goal of the paper is to analyse the existing position of immigrants on the Croatian labour market. Important characteristics of the Croatian labour market in recent years have been a high unemployment rate and high share of long-term unemployment. The effects of these adverse conditions are manifold, not only at the level of the economy (in terms of under-utilisation of available resources), but also at the level of affected individuals. Regarding individuals, the consequences of long-term unemployment frequently incorporate increased distance from the labour market due to the (perceived) loss of skills. The aim of the paper is to investigate individual characteristics that predict either unemployment or long-term unemployment of the immigrant population in Croatia.

The empirical analysis is based on the Labour Force Survey conducted by the Croatian Central Bureau of Statistics. Due to the data source used, the immigrant population is not defined on the basis of their nationality or citizenship. It entails all persons who were born outside Croatia and currently have permanent residence in the country. The second condition is directly related to the nature of the sample used for the Survey, where the sample frame relies on permanent residency. This implies that any short-term circular migrations (due to, for example, increased labour market during the tourist season) are probably not covered by the data. To the extent that this is important for the labour market outcomes of immigrants in Croatia, the scope of the results is limited.

In order to assess the effects of the crises on the labour market outcomes of immigrants in Croatia, the empirical analyses have been separately performed for two distinct years: the first one (a pre-crisis year) being 2007 and the second one (a crisis year) is 2012. The second analysed year refers to the period of deep economic crisis in Croatia, which had profound effects on the labour market. Thus, there is special interest whether the predictors of unemployment status have changed as a consequence. The choice of the unemployment status predictors is based on the standard set of individual characteristics, limited by their availability in the Labour Force Survey.

Descriptive analysis has revealed that there are important differences in the sample structure between the two analysed years. The average age of immigrants is higher in the year 2012, and they are more concentrated in urban areas. In both years, employed and unemployed immigrants are most likely to have upper secondary education. The structure of their occupations has significantly changed. While in 2007 the higher percentages of immigrants were employed craft and related trade workers, 
in 2012 their employment was higher in service and sales workers and professionals. The increased share of the unemployed with elementary occupation, as well as craft and related trade workers, and plant and machine operators occurred during the same period.

Due to the binary nature of dependent variables, empirical analysis rests on the probit methodology. The additional benefits of binary predictors have been utilized by exploring the size of the estimated marginal effects.

The analysis for the 2007 (pre-crisis) year has identified the following significant predictors of the unemployment status for immigrants in Croatia, listed in the decreasing marginal effects order:

- positive predictors: service and sales occupation and persons older than 55 (in comparison to 35-44)

- negative predictors: skilled agricultural, forestry and fishery workers and male persons.

The analysis for the 2012 (crisis) year has identified the following significant predictors of unemployment status for immigrants in Croatia, listed in the decreasing marginal effects order:

- positive predictors: elementary occupations, plant and machine operators, persons aged 15-24 (in comparison to the reference age cohort 35-44), craft and related trade workers, service and sales workers, persons older than 55 (in comparison to the reference age cohort);

- negative predictors: skilled agricultural, forestry and fishery workers and persons living in urban areas.

The analysis has revealed that traditional predictors of labour market outcome status have also been significant for the immigrant population in Croatia. It also reveals that they change over time. The occupation of the immigrant is more important in the crisis, which is probably related to the adverse demand effects of specific economic activities. Additionally, age has gained increased importance in the crisis, which is similar to the experiences of the domicile population.

The second segment of the analysis was focused on long-term unemployment. Unemployment is considered to be short-term if the person is in that status for less than a year (in accordance with the long-term unemployment definition used by the Eurostat) and very long-term if the person is in that status for more than two years. Descriptive statistics reveals that there is a higher share of persons with lower secondary education in the long-term unemployment sample, while the highest share, regardless of the duration of the unemployment, is reserved for upper secondary education. The data also reveal that the share of unemployed immigrants registered as unemployed at the public employment service increased in the crisis year, regardless of the duration of the unemployment. It is also interesting to note that the share of immigrants without prior working experience decreased in the crisis year, also regardless of the duration of their unemployment. Both factors indicate more active search in the crisis period and suggest demand constraints on the labour market, which has affected both the domicile and immigrant population.

In order to determine significant predictors of very long-term in comparison to short-term unemployment, the same empirical strategy has been applied. The analysis for the 2007 (pre-crisis) year has identified the following significant predictors of long-term unemployment status for immigrants in Croatia, listed in the decreasing marginal effects order:

- positive predictors: lower secondary education (in comparison to upper-secondary education), persons older than 55 and persons in the $45-54$ age cohort (in comparison to the reference 35-44 age cohort). 
The analysis for the 2012 (crisis) year has identified the following significant predictors of long-term unemployment status for immigrants in Croatia, listed in the decreasing marginal effects order:

- positive predictors: persons without prior working experience and persons older than 55 (in comparison to the reference age cohort);

- negative predictors: age cohorts 15-24 and 25-34 (in comparison to the reference age cohort), being married or cohabitating, male persons.

Comparing the results for 2007 and 2012 it seems obvious that the most important difference is related to first-time job seekers. The crisis has created a population without previous working experience that has become long-term unemployed. Since the long-term unemployed are, in general, considered by employers as persons with lower employability, this is a serious issue that deserves policy actions.

When considering future policy actions related to immigration, results for the most recent year are more important. The analysis in the paper has shown that certain occupations (elementary occupations, services and sales workers, crafts and related workers, and plant and machine operators) are connected with increased probability of being unemployed for the immigrant population. This clearly shows that it is important to identify the activities of future increased labour demand and supplement this information with skills and competencies in order to support active immigration policy. Furthermore, the higher probability of unemployment for the young and the old suggests that it is important to design specific measures to target the more active inclusion of this population in the labour market activities. Relying on prime-age population will not yield sufficient efforts to revive the labour market.

The results in the paper show that there are important differences in the predictors of labour market status of immigrants that have evolved in the course of the profound effects the latest economic crisis has had in Croatia. The identified predictors of unemployment or long-term unemployment for immigrants seem to be mostly similar to those of the domicile population. These results imply that the crisis has affected both population subgroups similarly, and that no additional segmentation of the labour market has occurred in that respect. However, the analysis has also pointed to the specific subgroups of both immigrant and native population (like the old, the young, persons without prior working experience), that seem to be adversely affected by the crisis.

The results presented strongly suggest that active immigration policy should also incorporate labour market policy measures and that these should be developed in parallel.

KEY WORDS: unemployment, long-term unemployment, immigrants, labour market, Croatia 